\title{
Additional Archaeological and Historical Studies for the Fairmount Hotel Project in San Antonio, Texas
}

Joseph H. Labadie

Follow this and additional works at: https://scholarworks.sfasu.edu/ita

Part of the American Material Culture Commons, Archaeological Anthropology Commons, Environmental Studies Commons, Other American Studies Commons, Other Arts and Humanities Commons, Other History of Art, Architecture, and Archaeology Commons, and the United States History Commons

Tell us how this article helped you.

This Article is brought to you for free and open access by the Center for Regional Heritage Research at SFA ScholarWorks. It has been accepted for inclusion in Index of Texas Archaeology: Open Access Gray Literature from the Lone Star State by an authorized editor of SFA ScholarWorks. For more information, please contact cdsscholarworks@sfasu.edu. 
Additional Archaeological and Historical Studies for the Fairmount Hotel Project in San Antonio, Texas

\section{Creative Commons License}

\section{(c) (i) (9)}

This work is licensed under a Creative Commons Attribution-NonCommercial 4.0 International License 


\section{ADDITIONAL ARCHAEOLOGICAL AND \\ HISTORICAL STUDIES FOR THE FAIRMOUNT HOTEL PROJECT IN SAN ANTONIO, TEXAS}

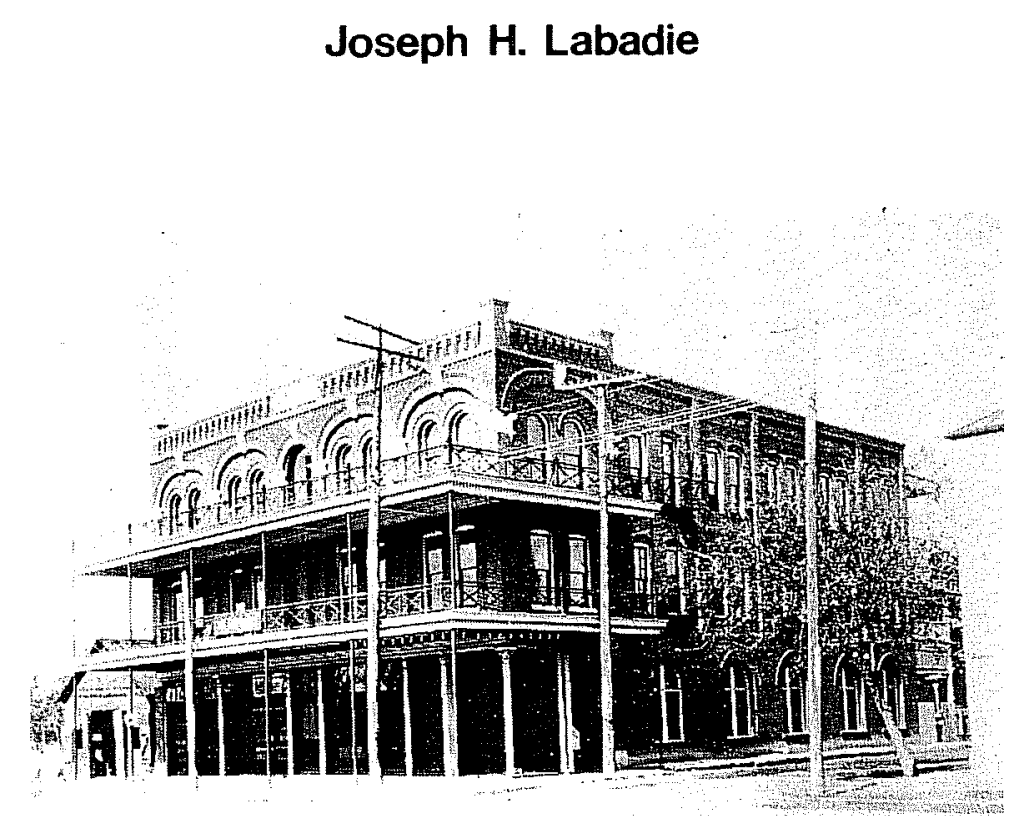

Center for Archaeological Research The University of Texas at San Antonio Archaeological Survey Report, No.160 1986 



\title{
ADDITIONAL ARCHAEOLOGICAL AND \\ HISTORICAL STUDIES FOR THE \\ FAIRMOUNT HOTEL PROJECT IN \\ SAN ANTONIO, TEXAS
}

\author{
Joseph H. Labadie
}

Texas Antiquities Committee Permit No. 505

Thomas R. Hester, Principal Investigator

Center for Archaeological Research The University of Texas at San Antonio ${ }^{\circ}$ Archaeological Survey Report, No. 160 
The following information is provided in accordance with the General Rules of Practice and Procedure, Chapter 41.11 (Investigation Reports), Texas Antiquities Committee:

1. Type of Investigation: Archaeological testing of the southern portion of New City Block 155, Lot 6, in downtown San Antonio, Texas;

2. Project Name: Fairmount II Project;

3. County: Bexar;

4. Principal Investigator, Thomas R. Hester; Co-Principal Investigator, Jack D. Eaton; Field Director and Author, Joseph H. Labadie;

5. Name and 1ocation of sponsoring agency: Alamo Architects and the Fairmount Hotel Company, San Antonio, Texas;

6. Texas Antiquities Committee Permit No. 505;

7. Published by the Center for Archaeological Research, The University of Texas at San Antonio 78285, 1986.

A 1 ist of publications offered by the Center for Archaeological Research can be obtained by sending $\$ 1.00$ to the Center for Archaeological Research, The University of Texas at San Antonio, San Antonio, Texas 78285. 


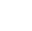




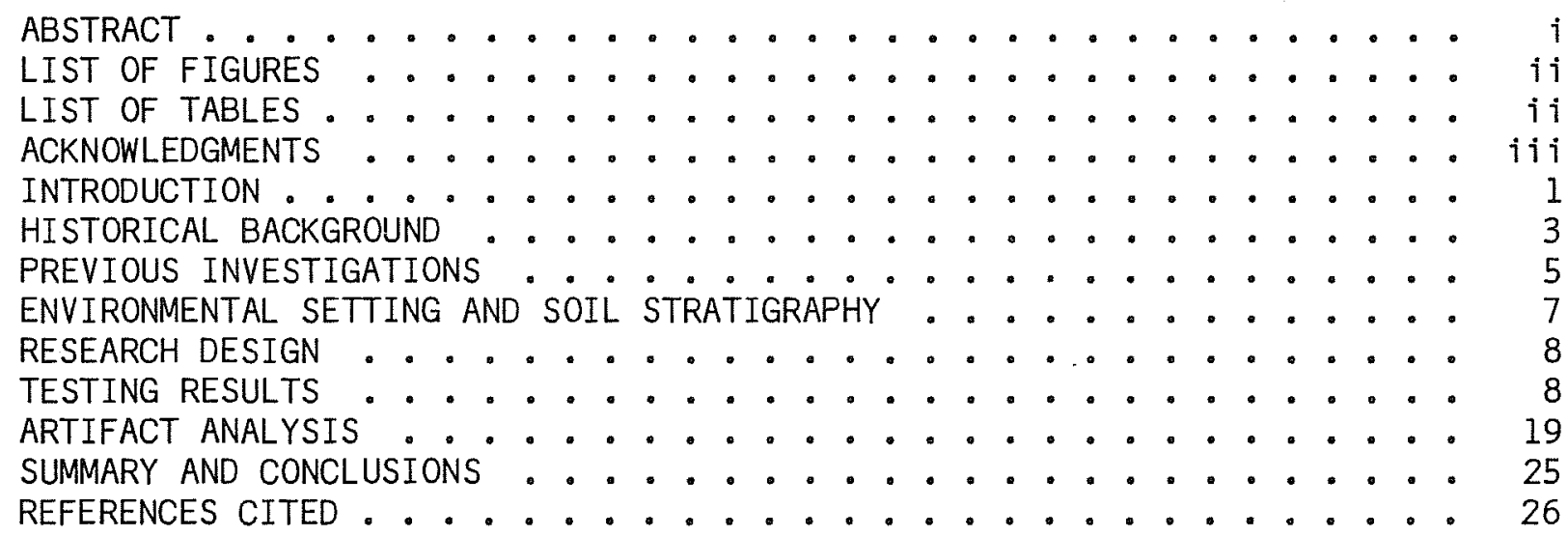

\section{LIST OF FIGURES}

1. Location of the Fairmount II Project Area on the Southern Portion of NCB 155, Lot 6, in Downtown San Antonio, Texas . . . . . . 2

2. View of La Villita Historical District in 1939 . . . . . . . . . . 6

3. A Facsimile of the 1904 Sanborn Insurance Map, Depicting the Structures on NCB 155 ..................... 9

4. Location of the Eight Backhoe Trenches on the Southern Portion of NCB 155, Lot 6, in Downtown San Antonio, Texas........ 10

5. Test Trench 1, East Wall Profile . . . . . . . . . . . . . 12

6. Selected 19th-Century Ceramics Recovered During Testing on the Southern Portion of NCB 155, Lot 6............. . 15

7. Test Trench 2, West Wa11 Profile . . . . . . . . . . . . 16

8. Test Trench 6, West Wal1 Profile . . . . . . . . . . . . . . . 18

9. Selected Late 19th-Century Glass Containers Recovered from Trench 6, Feature 1...................... . 21

10. Test Trench 7, North Wall Profile............... . 22

11. Test Trench 8, North Wall Profile................ 23

\section{LIST OF TABLES}

1. Compilation of Known Deed Records and Businesses Located on

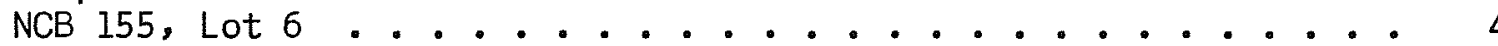

2. Compilation of Artifacts Recovered During Testing on the Southern Portion of NCB 155, Lot 6.............. 13 


\section{ACKNOWLEDGMENTS}

The author would 1 ike to thank Sharon Crutchfield, Director of the Daughters of the Repub 1 ic of Texas Research Library at the A1 amo, for her assistance with the archival research for this report. Additionalyy, she granted permission for the use of the photograph used in Figure 2. Mike McGlone, of Alamo Architects, provided the cover photograph of the Fairmount Hotel (ca. 1915), which is also part of the permanent collection of the Daughters of the Republ ic of Texas Research Library. Thanks is also extended to the field crew: George H. Deaton, Joe Tovar, and Kenneth Wright. A special thank you to Cathy Dodt for her assistance in the preparation of the map and figures used in this report. 



\section{INTRODUCTION}

During June 12-14, 1985, the Center for Archaeological Research (CAR), The University of Texas at San Antonio (UTSA) carried out an intensive archaeological testing program (designated the Fairmount II Project) on New City Block (NCB) 155, Lot 6, in downtown San Antonio, Texas. The project was done under contract with the Fairmount Hotel Company in advance of their planned development on the southern half of Lot 6. The testing program was conducted under the specific terms of the Texas Antiquities Committee Permit No. 505. The property tested is owned by the City of San Antonio and is leased to the Fairmount Hotel Company.

The northern half of NCB 155, Lot 6, had been investigated previousiy by the CAR-UTSA (February 16-March 1, 1985) under the terms of Texas Antiquities Committee Permit No. 480; this work was also done under contract with the Fairmount Hotel Company (Labadie 1986). These investigations (designated as the Fairmount I Project) resulted in the identification and excavation of La Villita Earthworks site (41 BX 677). The artifact collection recovered from La Villita Earthworks site has been designated a State Archeological Landmark within the 1 arger La Villita Historical District in downtown San Antonio.

The proposed development on the southern portion of Lot 6 involves a twolevel addition of three to four stories to the recently relocated historic Fairmount Hotel. The area is roughly equal to $(80 \times 90$ feet $)$, and adjacent to, that area investigated initial1y. The development necessitated the removal of a 11 earth in the southern half of Lot 6 to a depth roughly 10 feet below the present-day street level on South Alamo Street.

The new development will reach to within several feet of the German-Eng 1 ish School (established in 1858) 1ocated on Lot 5; this three-building complex has been designated as a Texas Historic Landmark. Development will also reach to within a few feet of Lot 7, which contains the Robert Caile House (ca. 1860), also a Texas Historic Landmark (see Fig. 1).

The purpose of this archaeological project was to evaluate the cultural resource significance of the southern portion of Lot 6 , its potential for nomination to the National Register of Historic P1 aces and as a State Archeological Landmark, and to determine if development would cause significant damage to subsurface deposits. The field work was conducted by George Deaton, Joe Tovar, Kenny Wright, and Joseph Labadie (Project Director) under the supervision of Dr. Thomas R. Hester, Center Director, and Jack D. Eaton, Associate Director. A1 1 field notes and materials recovered from testing are curated at the Center for Archaeological Research at The University of Texas at San Antonio. 


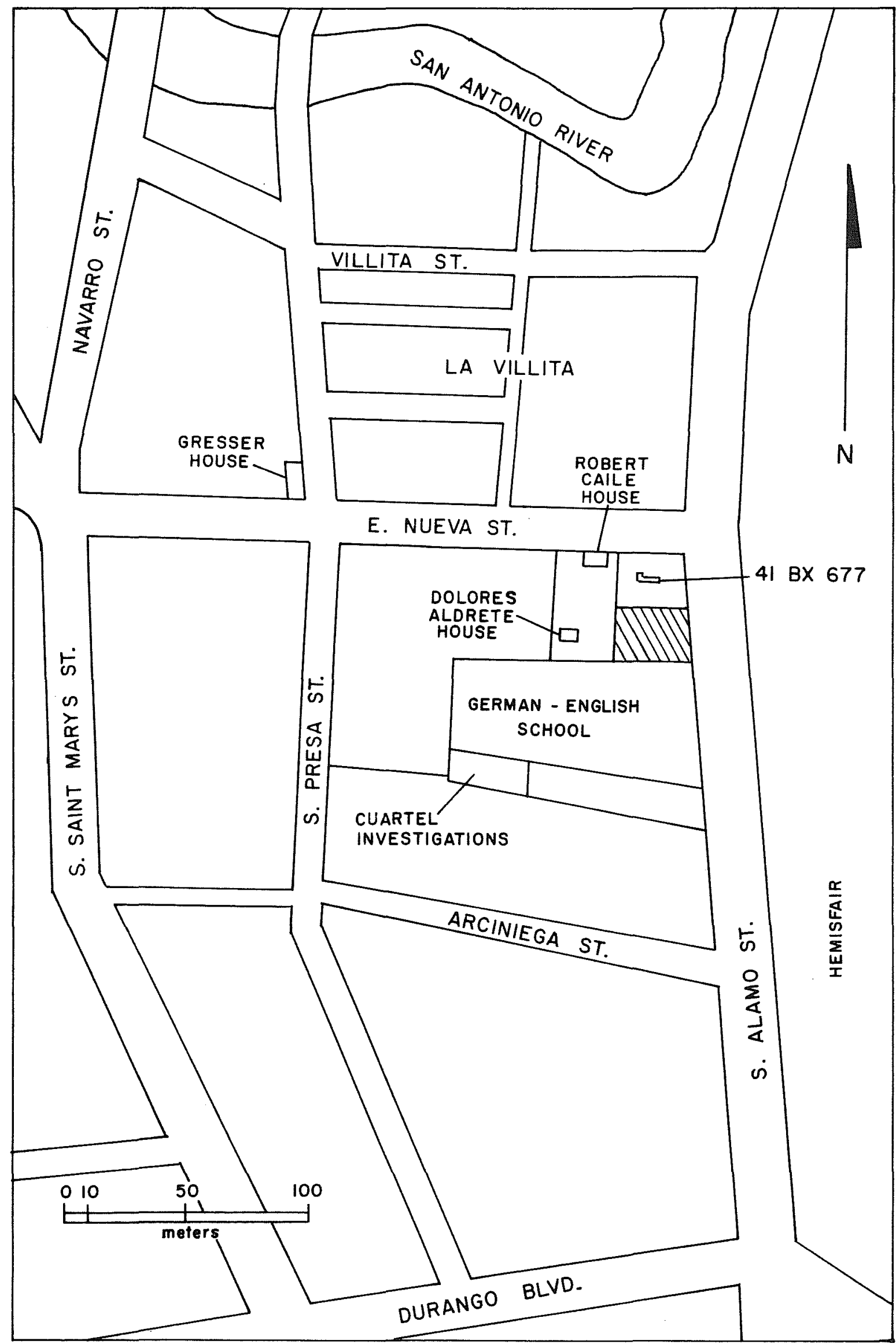

Figure 1. Location of the Fairmount II Project Area on the Southern Portion of NCB 155, Lot 6, in Downtown San Antonio, Texas. Crosshatch area represents southern portion of NCB 155, Lot 6 . La Vilitita Earthworks site (41 BX 677) was discovered during the Fairmount I Project on the northern portion of Lot 6. Adapted from Fox, Valdez, and Bobbitt (1978:Fig. 1). 


\section{HISTORICAL BACKGROUND}

The 1 and ownership for the property, known today as New City Block (NCB) 155, Lot 6 , can be traced back to the beginning of the settlement of San Antonio (see Table 1). By the middle 18th century, the general area around NCB 155 was referred to as the "Labor de Abajo." The lower 1abor area, delimited by the Concepcion Acequia on the west, the Acequia Madre on the east, the Alameda (Commerce Street) on the north, and the intersection of the two acequias on the south, was used for cultivation and pasturage during most of the 18th century. The area has rich alluvium from overbank flooding of the San Antonio River and would have had an abundant water supply from the two nearby acequias.

A11 records from the 18th-century period indicate that the lower 1 abor was unpopulated, although squatters or residents without legal title to the 1 and could well have occupied some portions. The constant threat of Indian depredations 1 imited the populated sections of the town to two main areas during most of the 18th century: (1) the Mission San Antonio de Valero (1ater known as the Alamo) compound on the east side of the San Antonio River; and (2) the area of the Presidio de Bexar on the west side of the river.

In 1793, the Viceroy of New Spain issued a decree cal1ing for the abandonment of Mission San Antonio de Valero. With the secularization of the mission, the role of the $A 1$ amo as a religious institution ended. The property and goods belonging to the mission were distributed to the mission Indians and residents, which included some 40 refugees from the abandoned Presidio of Adaes in east Texas (Habig 1939:68). The "Labor de Abajo" was surveyed and subdivided by Pedro Huizar and his assistant Vincente Amador (ibid.:37).

Who actually received title to the property now known as Lot 6 , following the initial 1 and distributions in 1793, is unknown. It was not until 1811 that the first recorded deed, which specifical1y mentions the area of NCB 155, appears in the Bexar County Deed Records (BCDR Vo1. LGS-40).

On December 29, 1802, a Spanish Cavalry unit, the Compañia Volante of San Carlos de Parras de Alamo from Chihuahua, was permanently reassigned to San Antonio and occupied the abandoned mission complex (Fox, Bass, and Hester 1976:6-7; Eaton 1980:6). By 1810, repairs and improvements, which included the addition of a fully equipped 30-bed hospital, had made the old mission complex a 1 ivable, and defensible, military outpost for Spain once again. Evidently, the old mission became known as the "Alamo" during this time.

The soldiers who were assigned to the Compañia probably 1 ived in and around the Alamo complex. Records from the time indicate that company members, and their families, were recorded as a distinct group with in the 1 arger populace of San Antonio in each census of the Compañia. A smal1 populated area southwest of the $A 1$ amo became known as the "barrio del Alamo" and undoubtedly housed some of the soldiers and families. By 1807, the area south of the Al ameda (present-day Commerce Street), along the west side of South A 1 amo Street, was being referred to as "La Vil1ita." Deed records for the next few years (1807-1810) witnessed a flurry of activity in lot sales and title transfers around the Alamo and the area of La Vil1 ita. After 1 ate 1810 , 
TABLE 1. COMPILATION OF KNOWN DEED RECORDS AND BUSINESSES LOCATED ON NCB 155, LOT 6

\begin{tabular}{|c|c|c|c|}
\hline \multicolumn{2}{|c|}{ Grantor } & \multirow[t]{2}{*}{ Grantee } & \multirow[t]{2}{*}{ Reference } \\
\hline 1718 & Spanish Government & & \\
\hline 1811 & Spanish Government & Clemente Delgado & BCDR Vo1. LGS-40 \\
\hline 1832 & Clemente Delgado & María Josefa Delgado & BCDR Vol. C-1:97-99 \\
\hline 1839 & Jose Antonio Delgado & John W. Smith & BCDR Vo1. A-2:221 \\
\hline 1848 & John W. Smith (decd) & Maria de Jesus de Lee (widow) & Inheritance \\
\hline 1852 & $\begin{array}{l}\text { sold at public auction } \\
\text { for back taxes }\end{array}$ & Joseph H. Beck & BCDR Vol. $K-2: 94$ \\
\hline 1853 & Joseph H. Beck & Durant Nobe1 & BCDR Vo1. K-2:547 \\
\hline $18 ? ?$ & $?$ & John Riddle & $?$ \\
\hline 1858 & John Riddle & Elizabeth M. Canterbury & BCDR Vol. P-2:550 \\
\hline 18?? & Elizabeth M. Canterbury & John W. and Mary L. Canterbury & $?$ \\
\hline 1880 & $\begin{array}{l}\text { John W. and Mary L. } \\
\text { Canterbury }\end{array}$ & James W. Riddle & BCDR Vol. 16:271 \\
\hline $18 ? ?$ & James W. Riddle & Elizabeth M. Canterbury & $?$ \\
\hline 1893 & Elizabeth M. Canterbury & Sarah M. Eager & BCDR Vol. $175: 258$ \\
\hline $19 ? ?$ & Sarah E. Eager & Casseb Brothers by 1927 & \\
\hline 1927 & $\begin{array}{l}\text { Pioneer Tire and Radio } \\
\text { Company }\end{array}$ & & $\begin{array}{l}\text { City Directory } \\
1927-1928\end{array}$ \\
\hline 1934 & $\begin{array}{l}\text { John A. Power opens a } \\
\text { gas station }\end{array}$ & & $\begin{array}{l}\text { City Directory } \\
\text { 1933-1934 }\end{array}$ \\
\hline $\begin{array}{l}1951- \\
1957\end{array}$ & $\begin{array}{l}\text { Lot } 6 \text { vacant at this } \\
\text { time }\end{array}$ & & \\
\hline $\begin{array}{l}1958- \\
1962\end{array}$ & $\begin{array}{l}\text { Frank A. Schroeder } \\
\text { Appliance Company }\end{array}$ & & \\
\hline $\begin{array}{l}1963- \\
1964\end{array}$ & $\begin{array}{l}\text { Lot } 6 \text { vacant at this } \\
\text { time }\end{array}$ & & \\
\hline 1964 & $\begin{array}{l}\text { Land is acquired by the } \\
\text { City of San Antonio }\end{array}$ & & \\
\hline 1985 & $\begin{array}{l}\text { Lot } 6 \text { is leased to the } \\
\text { Fairmount Hotel Company }\end{array}$ & & \\
\hline
\end{tabular}


there was a general hiatus in the sale and transfer of property everywhere in San Antonio following Hidalgo's Revolution in Mexico City. Beginning in late 1813-early 1814, and following three years of violence and property confiscations (by Casas in 1810 and Arrendondo in 1813) and several political-military administrations (Saucedo in 1810, Casas in 1811, Zambrano in 1812, Guiterraz-Magee in 1812, Arrendondo in 1813), San Antonio returned to another period of 1 imited tranquility.

In November 1811, Miguel Arciniega petitioned for and received a solar of 1 and south of La Vil 1ita a Tong South A 1 amo Street (BCDR Vo T. LGS-40). The property description in this deed noted that Arciniega's grant was "bounded on the north by the solar of $\mathrm{Clemente}$ Delgado with a street between [Arciniega Street]." The petition to the Spanish government and subsequent deed also noted that Cayentano Dominguez was the owner of the solar south of the Arciniega grant. Given this description, which has been cross-checked with several other deeds, Clemente Delgado's solar was located on NCB 155 , and fronted on South Alamo Street. His solar was separated from that of Arciniega's by a street; this street would eventually become known as Arciniega Street after the city was surveyed and platted by Francois Giraud in 1848 (Giraud 1848). Arciniega's solar was 1 located on NCB 901 and was a 1 so bounded on the east by South Alamo Street. The solar of Cayentano Dominquez would therefore have been located on NCB 903.

It is not known if Clemente Delgado, or his children, ever constructed a residence on the lot during their tenure of 1 and ownership (1811-1848). The deed records provide no indication one way or the other; no archaeological evidence was found to indicate a structure then, but such evidence might have been inconspicuous, removed by bul1dozing, or 1 ater disturbances.

The first residential structure, post-dating 1848, constructed on Lot 6 appears to have been the Canterbury-Riddle Homestead located on the northern portion of the lot. It would have been constructed after 1858, and may very wel1 be the structure depicted in the maps drawn by Augustus Koch in 1873 and 1886. This structure stood at the corner of East Nueva and South Alamo Streets until at least 1927, and was probably torn down due to the widening of East Nueva Street that same year.

Shortly after 1927, a gas station and a two-story brick commercial structure were built on Lot 6. Both structures were known to exist in 1939 (see Fig. 2). Both structures stood until the early 1960 s when the property was acquired by the City of San Antonio but were apparently razed shortiy thereafter. The lot was paved for parking to be used in connection with HemisFair in 1967.

\section{PREVIOUS INVESTIGATIONS}

Previous archaeological work has been conducted on the northern half of NCB 155, Lot 6 (Labadie 1986). Other archaeological investigations conducted in recent years on NCB 155 and adjacent city blocks, were a 1 so consulted. These projects are investigations at the Robert Caile and Dolores Aldrete Houses on Lots 7, 8, and 9 (Fox, Valdez, and Bobbitt 1978); investigations at a structure purported to be the remnants of a Spanish colonial structure 


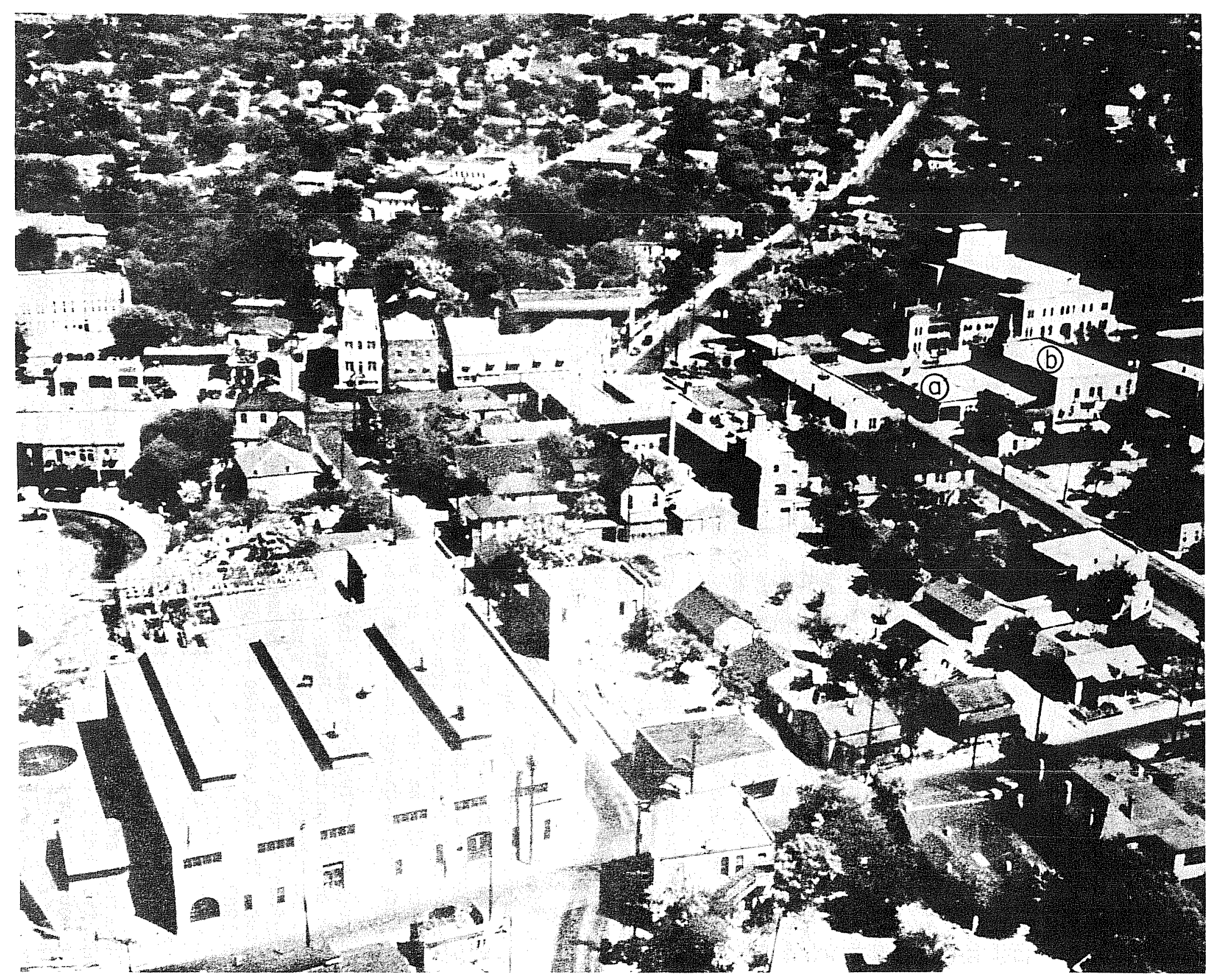

Figure 2. View of La Villita Historical District in 1939. The gas station at the corner of East Nueva Street (a) and the two-story commercial brick building (b) fronting on South Alamo Street are clearly visible (from Maverick 1939:21). 
known local1y as the "Quartel" on Lot 23 (Schuetz n.d.); investigations on the southern portion of NCB 155 and the Arciniega Street area (NCBs 901 and 902), now the Four Seasons Hotel (Katz 1978); and investigations at the Gresser House on NCB 125 (Ivey 1978). These archaeological investigations establ ished evaluative artifact chronologies (ceramic, glass, and meta 7 ) which form the nucleus for much of what is currently known about the area investigated during the Fairmount II Project.

\section{ENVIRONMENTAL SETTING AND SOIL STRATIGRAPHY}

The present-day environmental setting for the site area is one that is totally man-made. Concrete and modern landscaping have completely modified what was at one time a riverine environment adjacent to the San Antonio River. This area has been used in one capacity or another by the city's residents for over 250 years. Indeed, it is at times difficult to be sure with any certainty as to the presettlement ground surface location (Brown 1986).

NCB 155, Lot 6 sits on a low terrace of the San Antonio River, outside of and 1 ess than $200 \mathrm{~m}$ to the south of a 1 arge angu 1 ar meander of the river. The original surface of the terrace had an elevation of about 650 feet above mean sea level (ms 1), and is estimated at about $30 \mathrm{~cm}$ below the city bench mark (651.05 feet above ms 1) on the curb at South A1amo and East Nueva Streets.

The soil stratigraphy was revealed by the bul1dozing activities on the northern portion of NCB 155, Lot 6 (Fairmount I Project). A 1 arge square pit about $3 \mathrm{~m}$ deep, with a relatively consistent stratigraphic section was exposed in all the walls. Below the upper $30 \mathrm{~cm}$ or 50, consisting of modern concrete and gravel fi11, about $2.7 \mathrm{~m}$ of Quaternary sediments (probab1y Holocene in age) were exposed (ibid.). The upper $40 \mathrm{~cm}$ (approximately) is Houston Black clay, very plastic and dark gray brown (10 YR 3.1) in color, with a lower contact that is clear but very irregular (Brown 1986). This is a thinner solum than that reported by Taylor, Hailey, and Richmond (1966:21) for other Houston Black soils developed on terrace sediments, perhaps indicating some of the topsoil has been removed in this area (Brown 1986). Test pits dug in 1978 at the Caile and Dolores Aldrete Houses (NCB 155, Lots 7, 8, and 9) encountered this same dark brown soil as much as $60 \mathrm{~cm}$ below the modern ground surface (Fox, Valdez, and Bobbitt 1978). The occasional prehistoric artifacts found during the Fairmount I Project may have been displaced from this soil zone (Brown 1986). Below this soil was approximately $1.3 \mathrm{~m}$ of beige (10 YR 7.5/3) calichelike, very calcareous sediment, with a somewhat gritty texture, frequently partial ly indurated, with scattered smal1 (up to about $2 \mathrm{~cm}$ in diameter) gravel that was predominately calcareous, but included some chert. The lowest meter of the section was white chalky marl (10 YR 9/1). The highly calcareous nature of these sediments is a result of 01 mos Creek, the beginning of the drainage, heading in Edwards Limestone at the edge of the Balcones Escarpment, and the fine-grained nature of the alluvium indicates the limited sediment-carrying competence of the river near its head (Brown 1986). 


\section{RESEARCH DESIGN}

The research design for the Fairmount II Project involved essentially the same field strategy used to identify and isolate cultural deposits as on the northern half of Lot 6. The on 1 y major differences involved the use of machine-excavated testing units (Fairmount II Project) versus hand-excavated units (Fairmount I Project), and testing occurred prior to bul1dozing activities instead of concurrently as with the Fairmount I Project.

The entire surface area of the southern half of Lot 6 was arbitrarily gridded in $1-m^{2}$ units prior to the commencement of testing, to provide horizontal controls for mapping and locating test units. Eight backhoe trenches, deployed in a checkerboard pattern, were machine excavated. Al1 resulting profiles from these trenches were carefuliy examined for intrusive features, such as building foundations and trash disposal areas, to a depth of approximately seven feet below the street level on South Alamo Street. Concentrations of cultural materials and foundations were plotted and recovered by collection stations (which equal to grid plottings) within each trench; the soil was not screened.

Historical and archival research indicated that the highest probability areas for locating buried 19th-century deposits existed along the southern and western property 1 ines. The 1904 Sanborn insurance map (Sanborn Map and Publishing Company, Ltd. 1904) depicts what appears to be a stable (ca. 30 feet north-south $\times 9$ feet east-west) and one outbuilding (ca. 10 feet north-south $\times 9$ feet east-west; see Fig. 3). The southern 1 imit of the lot is within ca. 10 feet of one of the German-English School buildings; the possibility of finding buried debris related to the construction of this building was highly probable. Except for these two areas, much of the remaining surface area would have been at one time covered by an early 20 thcentury, two-story, brick commercial structure. As a result of the construction of this building, any 19th-century structural foundations or cultural features would have been badly disturbed.

Subsurface testing of the entire southern half of Lot 6 was not possible. An asphalt parking surface covers the majority of the area, with construction debris from the relocation of the Fairmount Hotel 1 ittering the length of the western boundary of the lot. The southern boundary of the lot is covered by a Saltillo tile sidewalk; no tiles were removed for testing. The eastern boundary of the lot is covered by a concrete sidewalk and a construction tool shed. The northern boundary of the area tested was clear of surface obstructions.

\section{TESTING RESULTS}

Eight machine-excavated trenches, a 11 rough 1 y $10 \mathrm{~m}$ in 1 ength, were excavated to a depth of nearly $2.5 \mathrm{~m}$, which was the maximum depth that could be achieved by the backhoe operator (Fig. 4). Soi 1 removed from the trenches was not screened, but each bucket of earth removed was inspected by a crew member. Another crew member inspected the trench after the removal of each bucket of earth in order to check for any damage to intact cultural features, such as the earthworks feature identified on the northern portion of Lot 6. 


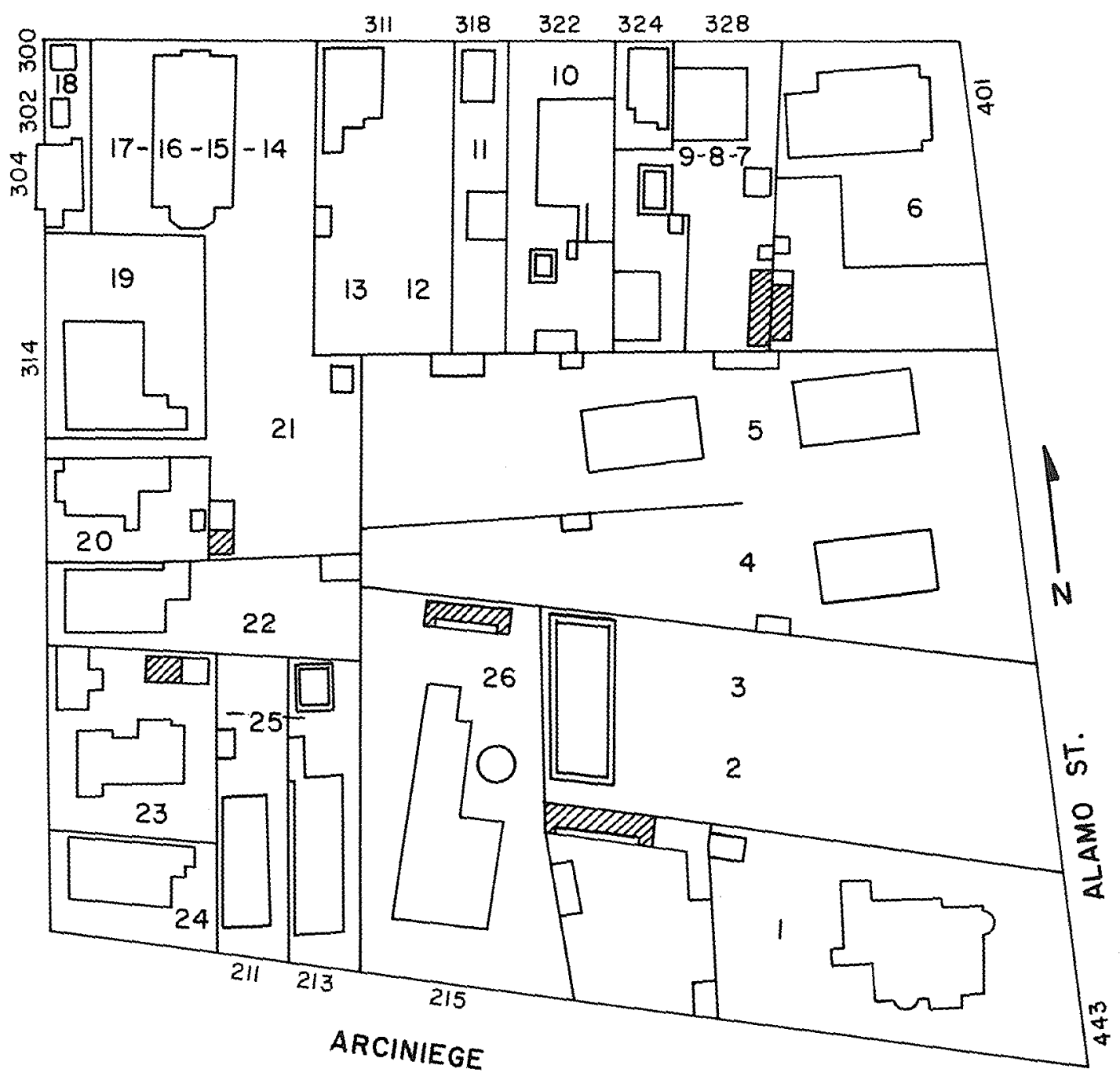
UIIA stable
igure 3. A Facsimile of the 1904 Sanborn Insurance Map, Depicting the
structures on NCB 155 . Taken from Sanborn Map and Publishing Company, Ltd. (1904). 


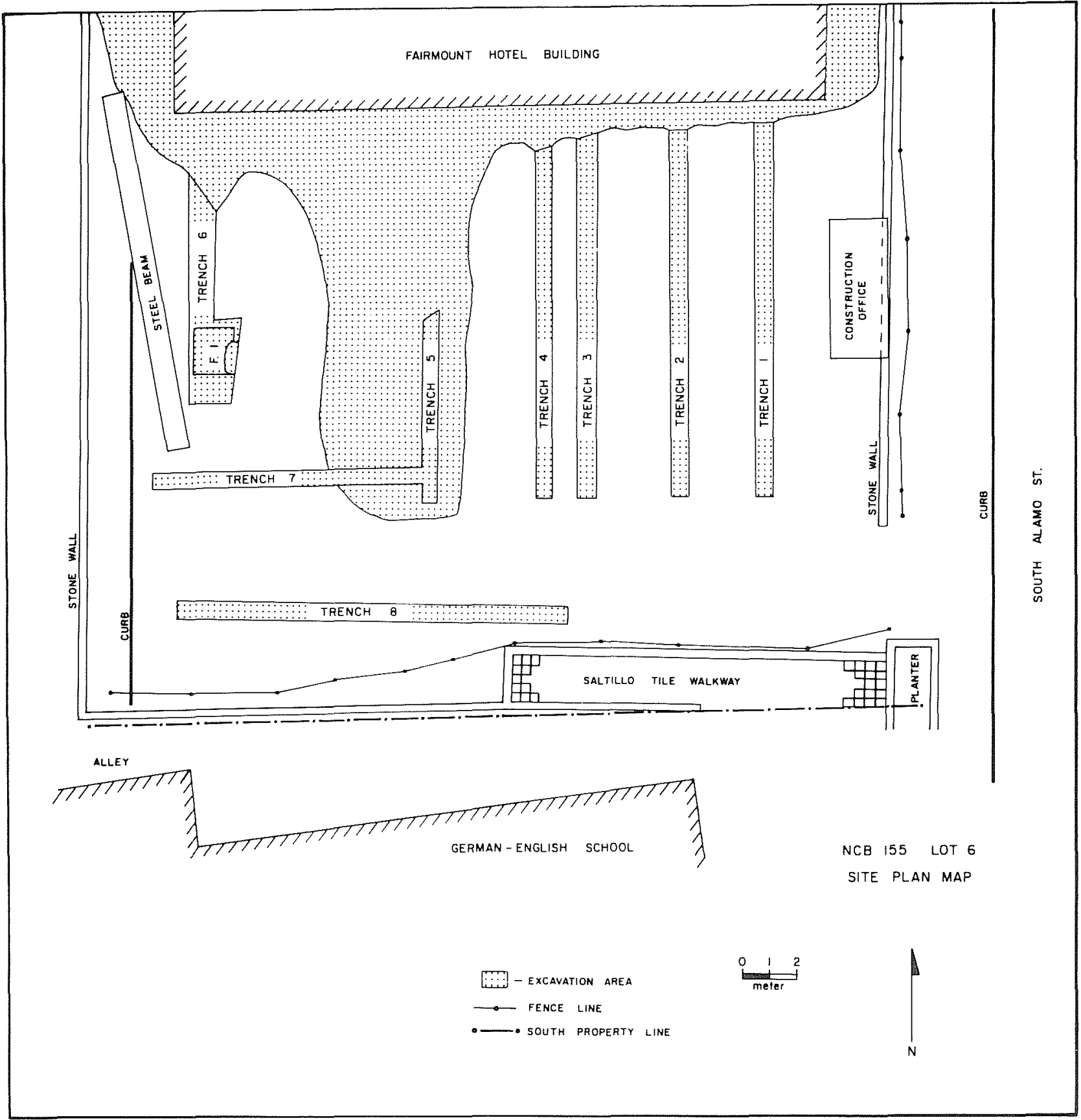

Figure 4. Location of the Eight Backhoe Trenches on the Southern Portion of NCB 155, Lot 6, in Downtown San Antonio, Texas. 
The spacing of the trenches was such that any subsurface feature that had a long axis greater than $1 \mathrm{~m}$ could be found and isolated by hand excavation, such as was done in Trench 6, Feature 1. A discussion of each test trench follows.

\section{Irench 1}

The top $50 \mathrm{~cm}$ of the vertical soil profile of Trench 1 indicated that modern disturbance, associated with construction and/or demolition of a 20th-century brick building, had badly disturbed the subsurface soil along the entire length of the profile facing South Alamo Street (Fig. 5). The western profile exhibited much of the same disturbances. There were no discrete cultural features or charcoal/ashen 1enses. Seventy-one artifacts were recovered from this trench (Table 2). Of these artifacts, only four ceramic sherds appear to be attributable to 19th-century manufacture: (1) a blue feather-edged decorated sherd; (2) a body sherd from a pearlware teacup (Fig. 6,k); (3) a rim sherd from a pearlware teacup (Fig. 6,i); and (4) a basal sherd of undecorated pearlware. The remainder of the materials from Trench 1 appears to be modern (20th century, Table 2).

\section{Irench 2}

Inspection of the vertical soil profile of Trench 2 revealed subsurface disturbances to a depth of $2.10 \mathrm{~m}$ (Fig. 7). No discrete cultural deposits were identifiable. A total of 41 artifacts was recovered within the disturbed soil zone (Table 2). Of these artifacts, on 1y three ceramic sherds appear to be attributable to 19th-century manufacture. Al1 three are of a ceramic type known as majolica (blue floral pattern; Fig. 6,a-c). Sherds of this type are common at many of the early 19th-century sites in San Antonio (Fox, Bass, and Hester 1976:47; Eaton 1980:28).

\section{Trench 3}

Trench 3 exhibited a similar profile as Trenches 1 and 2 . A total of 40 artifacts was recovered from the upper zone of modern disturbance and included four pearlware ceramic sherds which were manufactured during the 19th century (Table 2). These included: (1) a pearlware rim sherd; (2) a b 1 ue transfer-printed pearlware sherd (Fig. $6, h$ ); (3) a double transferprinted pearlware sherd (Fig. 6,d). Trench 3 did not contain any significant cultural features, foundations, or ashen lenses.

\section{Trench 4}

A tota 1 of 85 randomly distributed artifacts was recovered from the backdirt removed from Trench 4. Near 7 y $75 \%$ of these materials was from the 20 thcentury construction and/or demolition activities (window glass, cut wire nails, ceramic sewer pipe; Table 2). Al1 materials were recovered from disturbed contexts as no discrete features or deposits were defined. Five 


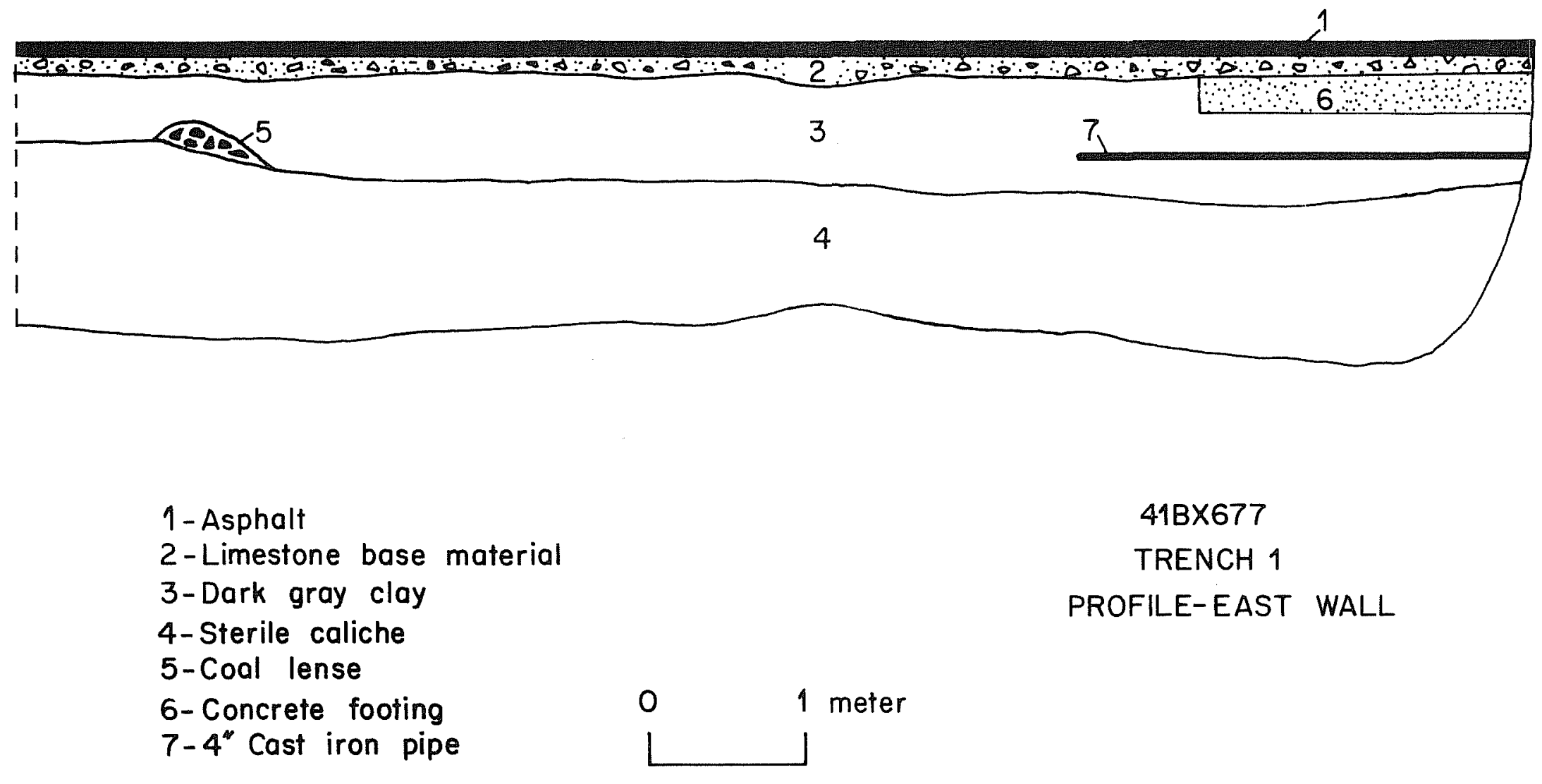

Figure 5. Test Trench 1, East Wall Profile. 
TABLE 2. COMPILATION OF ARTIFACTS RECOVERED DURING TESTING ON THE SOUTHERN PORTION OF NCB 155, LOT 6

\begin{tabular}{|c|c|c|c|c|c|c|}
\hline Artifacts & $\begin{array}{c}\text { Trench } \\
1\end{array}$ & $\begin{array}{c}\text { Trench } \\
2\end{array}$ & $\begin{array}{c}\text { Trench } \\
3\end{array}$ & $\begin{array}{c}\text { Trench } \\
4\end{array}$ & $\begin{array}{c}\text { Trench } \\
6 *\end{array}$ & $\begin{array}{c}\text { Trench } \\
7\end{array}$ \\
\hline $\begin{array}{l}\text { Ceramics } \\
\text { Majolica } \\
\text { Whiteware (decorated) } \\
\text { Whiteware (undecorated) } \\
\text { Pearlware (transfer) } \\
\text { Pearlware (undecorated) } \\
\text { Stoneware } \\
\text { Earthenware } \\
\text { Porcelain }\end{array}$ & $\begin{array}{l}2 \\
1 \\
1 \\
3\end{array}$ & 2 & $\begin{array}{l}3 \\
4 \\
3 \\
1\end{array}$ & $\begin{array}{l}3 \\
1 \\
1\end{array}$ & $\begin{array}{r}4 \\
21 \\
2 \\
4 \\
1 \\
1 \\
10\end{array}$ & $\begin{array}{l}1 \\
1 \\
8 \\
7 \\
2 \\
2\end{array}$ \\
\hline $\begin{array}{l}\text { Glass } \\
\text { Clear (flat) } \\
\text { Clear (bottle) } \\
\text { Green (a11 shades) } \\
\text { Brown } \\
\text { Aqua } \\
\text { White } \\
\text { Complete vessels } \\
\text { Stemmed glassware }\end{array}$ & $\begin{array}{l}1 \\
3 \\
2 \\
1\end{array}$ & $\begin{array}{l}6 \\
2\end{array}$ & $\begin{array}{l}4 \\
2 \\
1 \\
1 \\
4 \\
4\end{array}$ & $\begin{array}{l}9 \\
2 \\
4 \\
6 \\
4\end{array}$ & $\begin{array}{r}13 \\
1 \\
10 \\
10 \\
21 \\
6 \\
23 \\
16\end{array}$ & $\begin{array}{r}12 \\
39 \\
9 \\
2 \\
4 \\
2\end{array}$ \\
\hline $\begin{array}{l}\text { Meta1 } \\
\text { Iron } \\
\text { Copper } \\
\text { Brass }\end{array}$ & & & & & $\begin{array}{l}3 \\
2 \\
1\end{array}$ & 51 \\
\hline Bone & 25 & 4 & 2 & 14 & 140 & 34 \\
\hline Construction Materials & 24 & 19 & 14 & 41 & 80 & 31 \\
\hline Household Furnishings & 1 & 1 & & & 42 & 5 \\
\hline Personal Items & 1 & 1 & & & & 2 \\
\hline Prehistoric Remains & 1 & & 1 & & & 2 \\
\hline Activities & 5 & & & & & 18 \\
\hline Miscel 1 aneous & & & & & 2 & 1 \\
\hline Total & 71 & 41 & 40 & 85 & 413 & 235 \\
\hline
\end{tabular}

*Feature 1

Note: No artifacts were recovered from Trenches 5 and 8. 
Figure 6. Selected 19th-Century Ceramics Recovered During Testing on the Southern Portion of NCB 155, Lot 6.

a-c, Spanish colonial period majolica sherds, blue floral design, Trench 2;

d, double transfer-printed (black over blue) pearlware, Trench 3;

e, blue transfer-printed (floral pattern) pearlware, Trench 7;

$f$, red transfer-printed (floral pattern) pearlware, Trench 7;

g, blue transfer-printed pearlware, Trench 4;

$h$, blue transfer-printed (f1own-b1ue pattern) pear 1 ware, Trench 3;

i, blue transfer-printed pearlware rim sherd from a teacup, Trench 1;

$j$, red transfer-printed pearlware sherd from a saucer, Trench 7;

k, black transfer-printed pearlware sherd from a teacup, Trench 1;

1, blue transfer-printed (scenic pattern) pearlware sherd from a plate, Trench 7;

$m$, red transfer-printed and hand-painted pearlware sherd from a plate, Trench 6;

$\mathrm{n}$, banded slipware (black bands on blue), Trench 7;

0 , hand-painted whiteware teacup saucer, Trench 6 , Feature 1.

Artifacts are shown at actual size. 

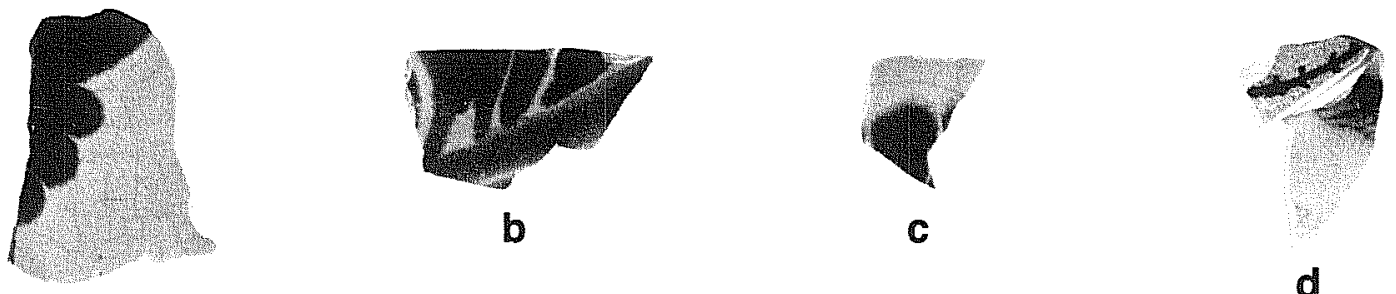

d

a

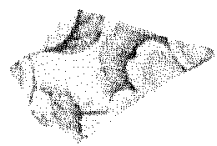

e

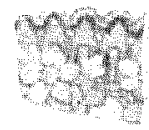

f

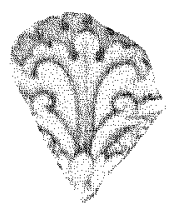

g

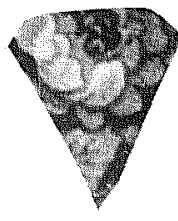

h
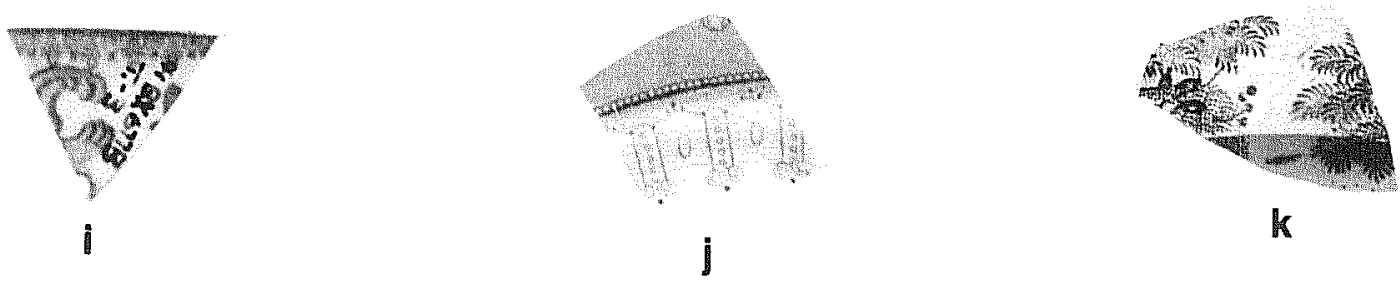

- 11

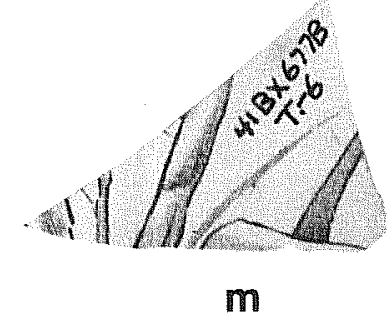

I
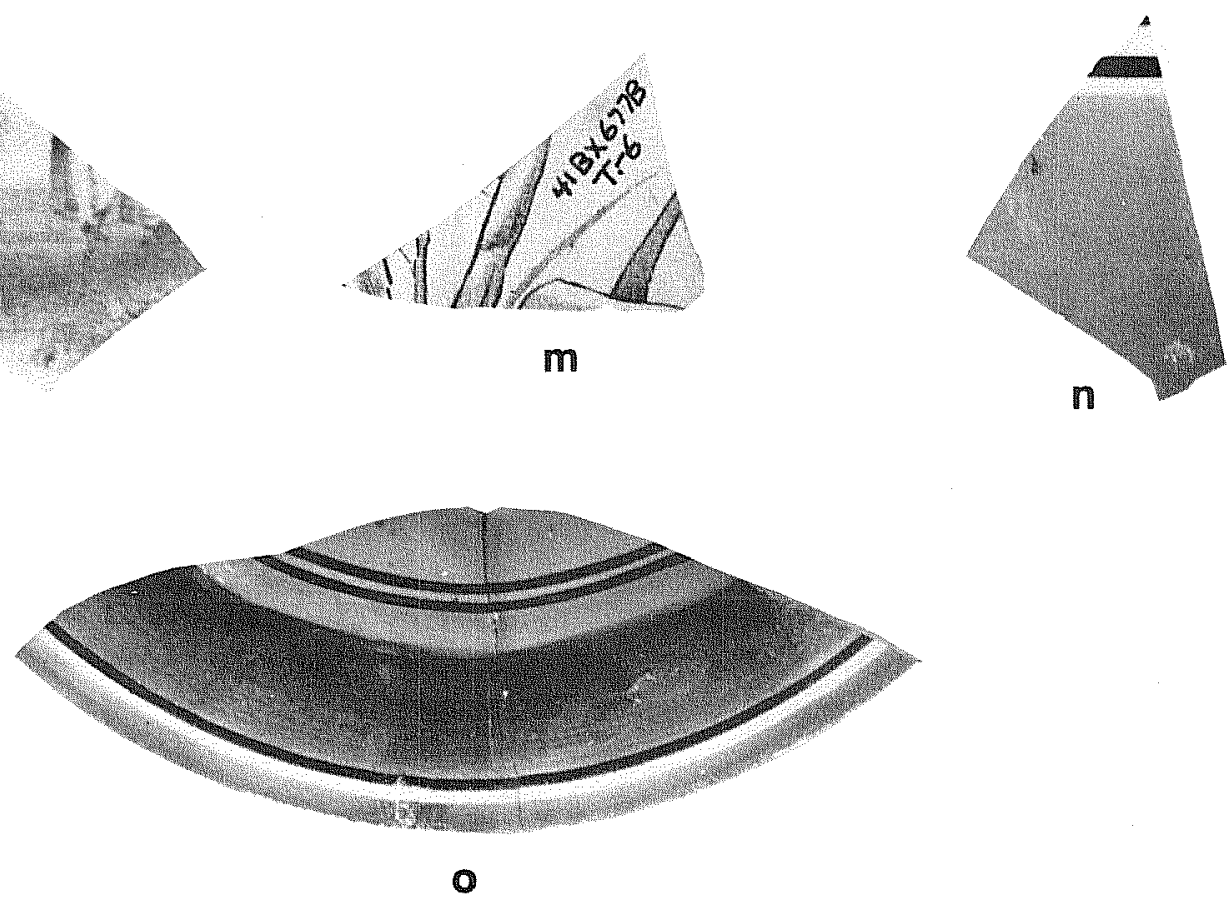


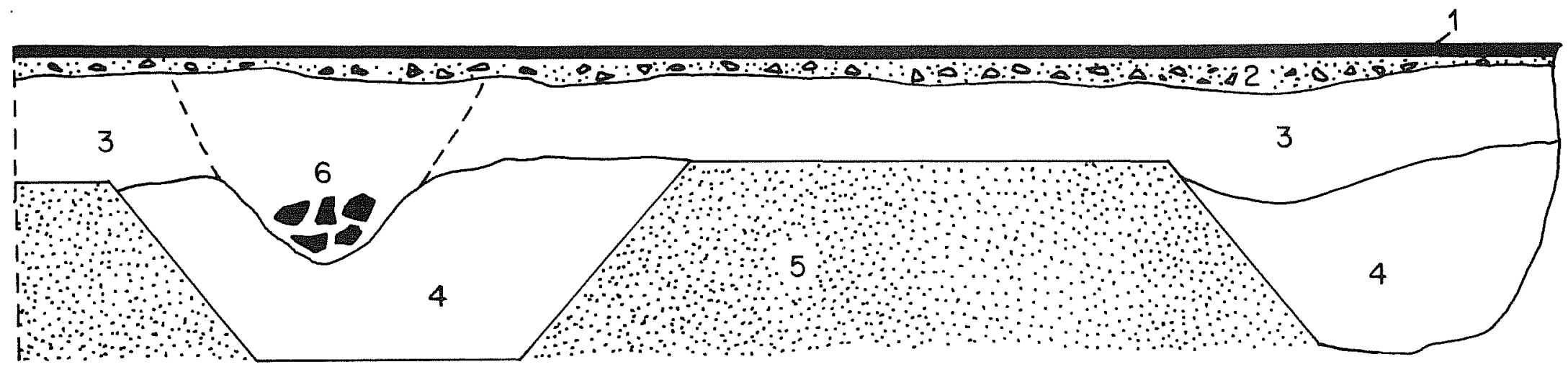

1- Asphalt

2-Limestone base material

3-Dark gray clay

4-Caliche

5-Concrete footings

6 -Brick wall fragments

$\begin{array}{ll}0 & 1 \text { meter } \\ L & 1\end{array}$

\author{
$41 \mathrm{~B} \times 677$ \\ TRENCH 2 \\ PROFILE-WEST WALL
}

Figure 7. Test Trench 2, West Wall Profile. 
ceramic sherds were among the artifacts, only one of which can be attributed to the late 19th century (Fig. 6,g).

\section{Irench 5}

Trench 5 exhibited a vertical soil profile not unlike Trenches 1 through 4. Modern disturbances extended to a depth of $30 \mathrm{~cm}$ below the street level on South Alamo Street (651.08 feet above ms 1 ). Inspection of the soils from this trench failed to produce a single artifact. No discernible cultural features could be identified in either the west or east profile.

\section{Irench 6}

Trench 6 produced the on $1 y$ intact cultural feature identified during the testing on the southern portion of NCB 155, Lot 6 (Fig. 8). The backhoe operator exposed a 1 inear north-south feature composed of a single row of bricks; hand excavation quickly isolated two $90^{\circ}$ corners. The soil matrix within this bricked feature consisted of burned coal and cinders. The soil also contained badly oxidized fragments of metal.

Feature 1 was excavated to a depth of $2.4 \mathrm{~cm}$ below the level where it was first recognized $(650.88$ feet above $\mathrm{ms} 1)$. The upper $50 \mathrm{~cm}$ consisted of a coa 1-cinder matrix with several identifiable thin lenses (1ess than $3 \mathrm{~cm}$ thick) of oxidized iron fragments. A smal1 number of ceramic whiteware sherds (Fig. 6,0), animal bone, and glass fragments were intermixed in this upper zone. At $1.5 \mathrm{~m}$ below the top of this feature, a 1 arge number of animal bones, complete glass bottles (Fig. 9,a-e), construction debris, metal fragments (brass, copper, and iron), stemmed glassware, and several toys (leather ball fragment and a ceramic marble) were found.

The entire contents of Feature 1 were removed by hand excavation without the use of arbitrary 1eve1s. Most of the classifiable artifacts (complete bottles, ceramic sherds) date to the late 19th century to early 20th century. Few artifacts with manufacturing dates before the Civil War (1860) were recovered (Fig. $6, \mathrm{~m})$. The construction of this feature, with a fire brick lining from top to bottom, as wel1 as its location on the 1ot, could indicate that it represents an old incinerator where trash has been burned. It is interesting to note that not a11 artifacts were thermal1y altered (e.g.s on $1 \mathrm{y}$ 14 of the 140 bones recovered had been burned). There were several alternating 1 ayers of debris which represent different episodes of burning trash followed by an episode of burning without trash, or the disposal of trash without in situ burning. A total of 413 artifacts was recovered from Feature 1 (Table 2).

Historical research failed to pinpoint the construction date for this feature. The temporal placement for the diagnostic artifacts seems to indicate a no-earlier-than-date for construction of 1860. Several artifacts in the upper zones indicate that Feature 1 was in use through the early 20th century. 


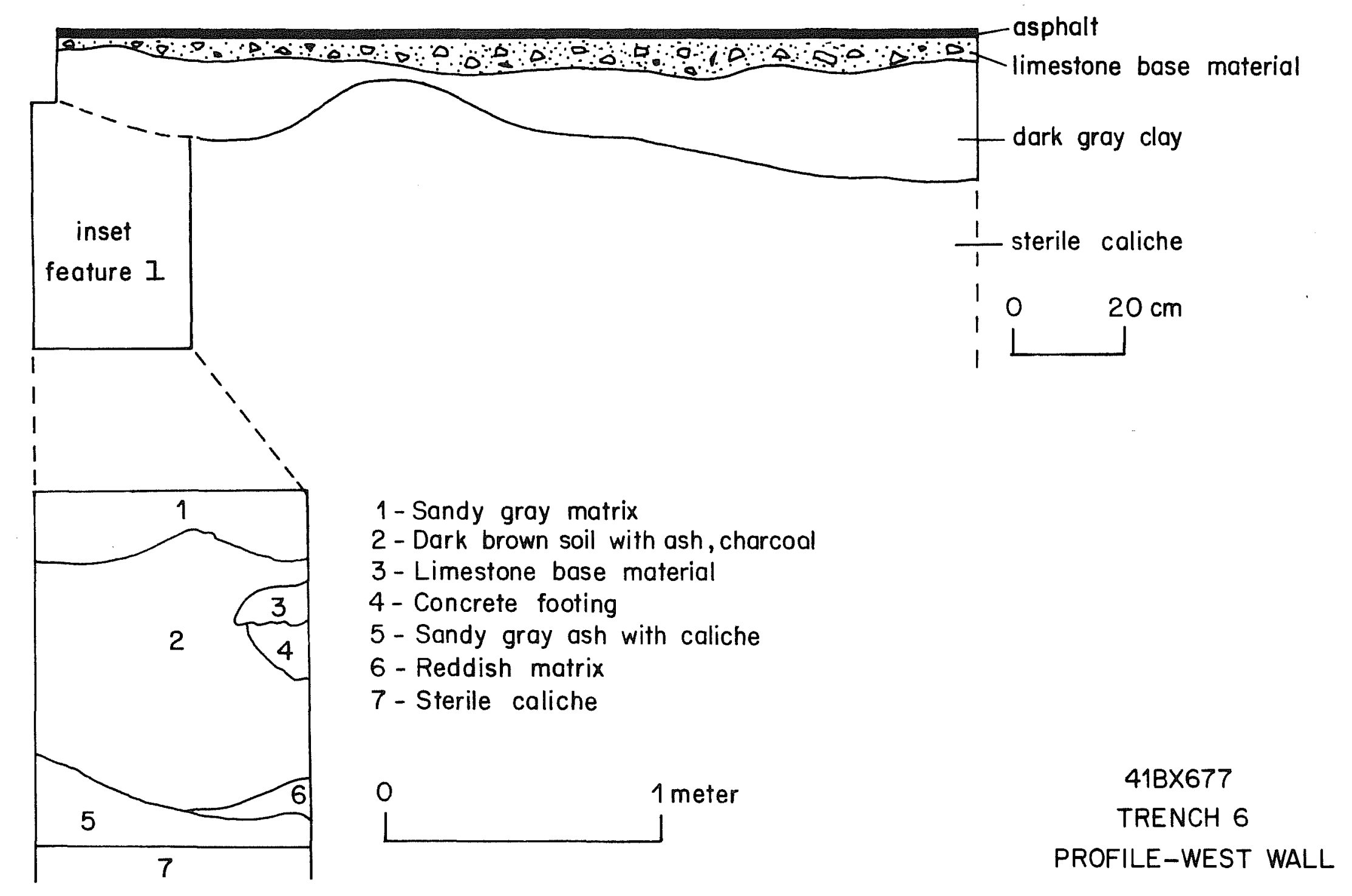

FEATURE $I$

NORTH WALL PROFILE

Figure 8. Test Trench 6, West Wal1 Profile. 
The 1904 Sanborn insurance map (Sanborn Map and Pub1ishing Company, Ltd. 1904) depicts a structure slightly larger than Feature 1 in this approximate location (Fig. 3). The structure depicted appears to be an outbuilding associated with a horse stable; it could very we11 have been a storage room for horse equipment or blacksmith shop. The archaeological evidence is insufficient to support the thesis that Feature 1 represents the remnants of a blacksmith shop or a storage room for horse equipment, and of the 413 artifacts recovered from Feature 1, 304 items reflect domestic activities (ceramics, beverage bottles, patent medicine bottles, chimney glass, stemmed glassware, 1 ight bulb fragments). Neither can Feature 1 be directly associated with the two-story brick commercial building which once stood on the southern portion of Lot 6 . The feature may have been used by the occupants of that building after 1927, as evidenced by the light bulb fragments and 20 th-century glass and bottle fragments, but it was not constructed for use in connection with the operation of that building.

\section{Irench 7}

Trench 7 contained the highest frequency of randomly distributed artifacts observed during testing (Table 2). A11 235 items were recovered from the backdirt which had been removed from the upper zone of modern disturbance (Fig. 10). Roughly 50\% of the materials represents 20th-century construction and/or demolition activities on the 1ot, with about $30 \%$ representing domestic activities ( $g$ lass beverage bottle fragments, animal bones [mostly beef, e.g., round steak, T-bone steak], whiteware, stoneware, earthenware, and porcelain ceramic sherds). At least seven of the decorated pearlware sherds are of 19th-century European manufacture (five sherds are illustrated in Fig. $6, e, f, j, 1, n)$.

\section{Irench 8}

Trench 8 consisted almost entirely of a concrete building foundation (Fig. 11). The foundation had totally disturbed al1 subsurface deposits to a depth of $1.7 \mathrm{~m}$. Inspection of the backdirt failed to produce a single artifact.

\section{ARTIFACT ANALYSIS}

The 885 artifacts recovered during testing were classified using standard 1 aboratory procedures and analyzed with the existing chronologies which have been developed over the years from the many historical archaeological projects conducted by the CAR-UTSA in downtown San Antonio and the surrounding areas. Both technological and descriptive analytic methods were used as part of this study.

Artifacts were classified according to the major material used in its construction (e.g., glass, meta 1 ); the analysis of these classes of artifacts focused mainly on the technology used to manufacture the item. Industrial or machine-produced items have tel1tale marks or indicators left by the type of machine used to produce the item. In many cases, the introduction date for a 
Figure 9. Selected Late 19th-Century G1ass Containers Recovered from Trench 6, Feature 1.

a, medicinal container with embossed lettering, "DT. C. F. BROWN'S YOUNG AMERICAN LINIMENT, NEW YORK";

b, pharmaceutical container with embossed lettering, "SILVERTHORN \& WAGNER, PRESCRIPTION DRUGGISTS, SAN ANTONIO, TEX";

c, patent medicine bottle with embossed lettering, "DR. T. W. GRAYDON, CINCINNATI, OH, DISEASES OF THE LUNGS";

d, Vaseline container with embossed lettering, "TRADE MARK VASELINE, CHESEBROUGH, NEW YORK";

e, Levi-Garrett snuff bottle with hand-tooled 1 ip.

Bottles are shown at actual size. 

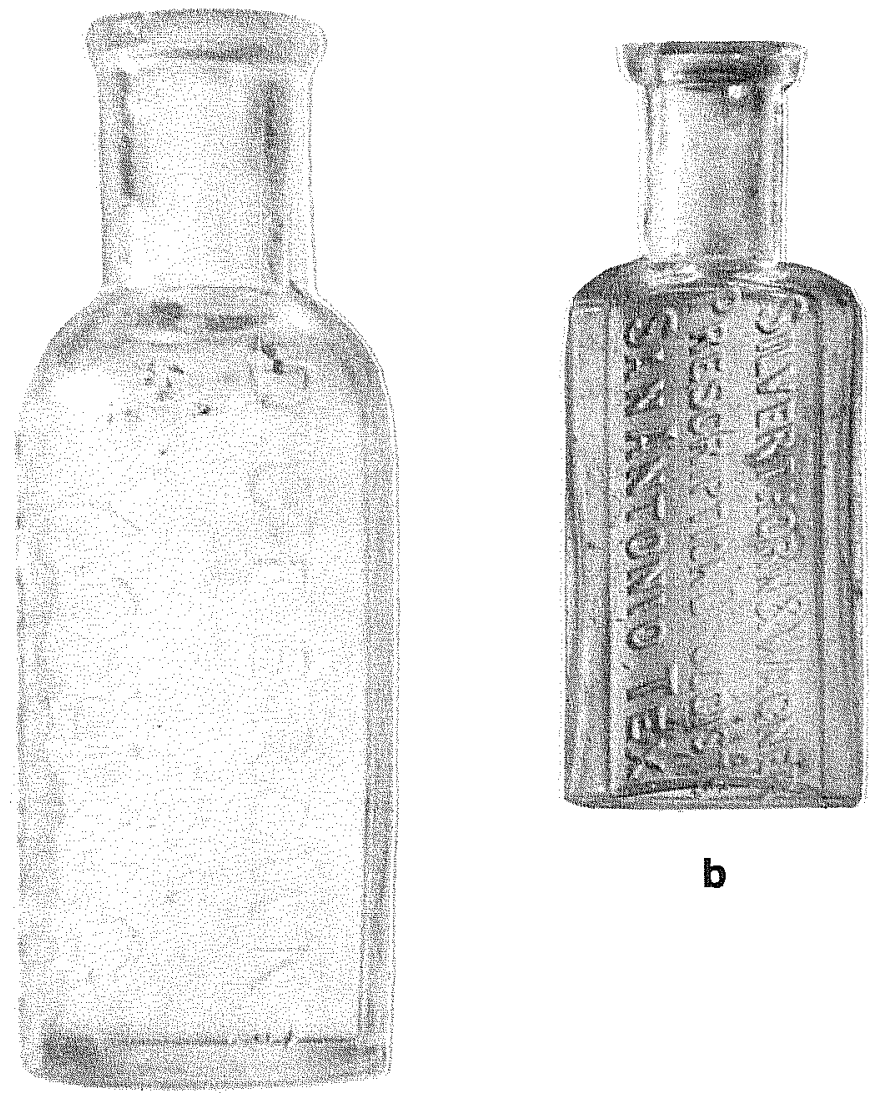

b

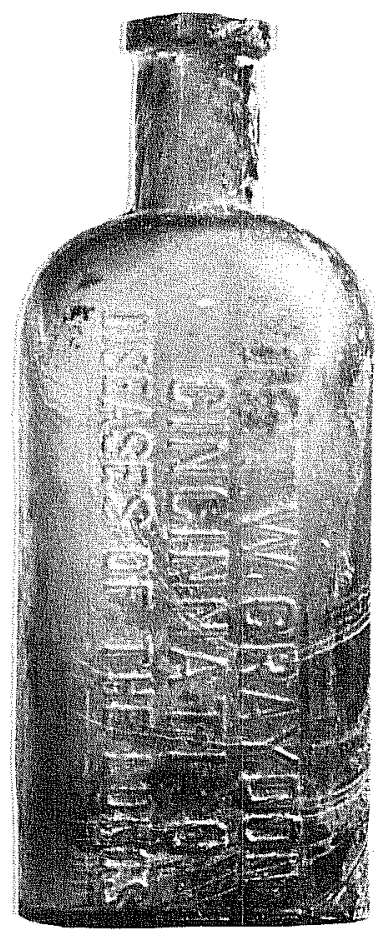

C

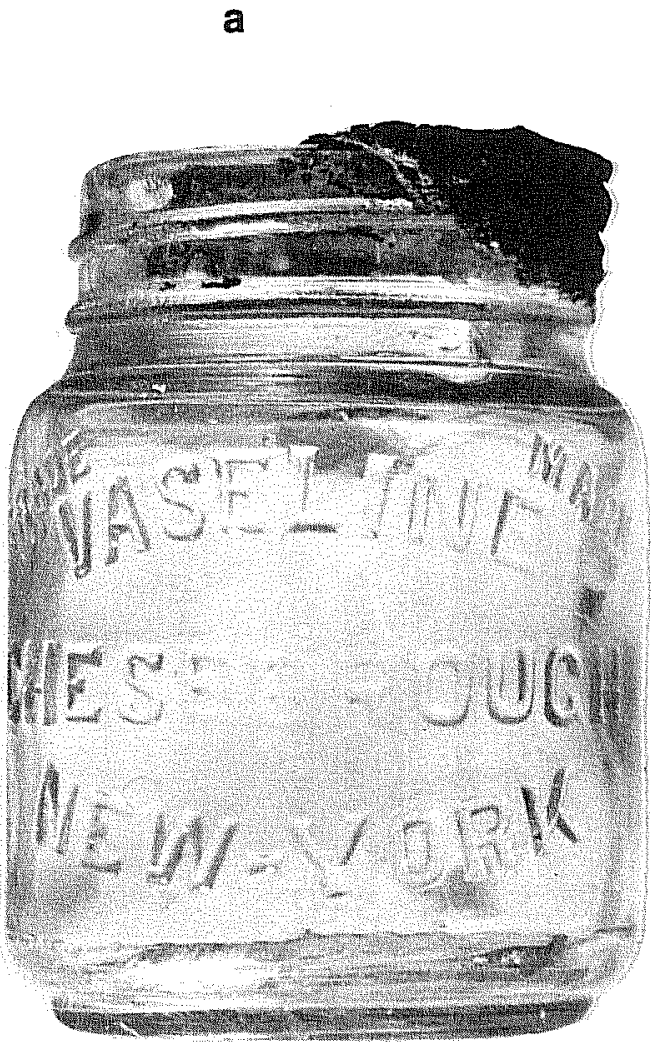

d

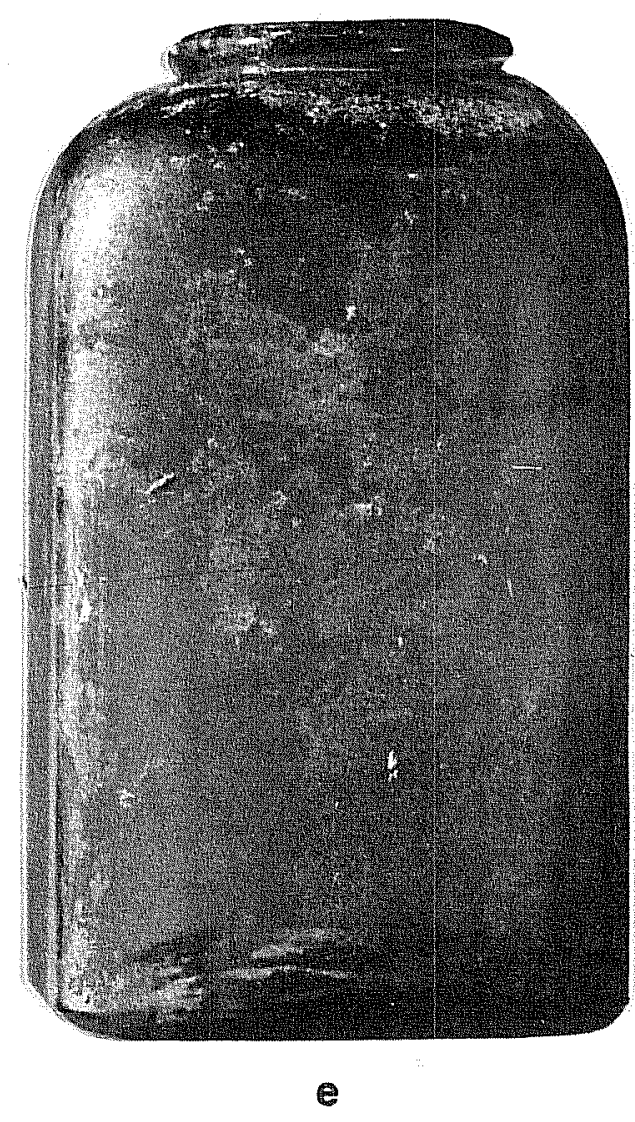




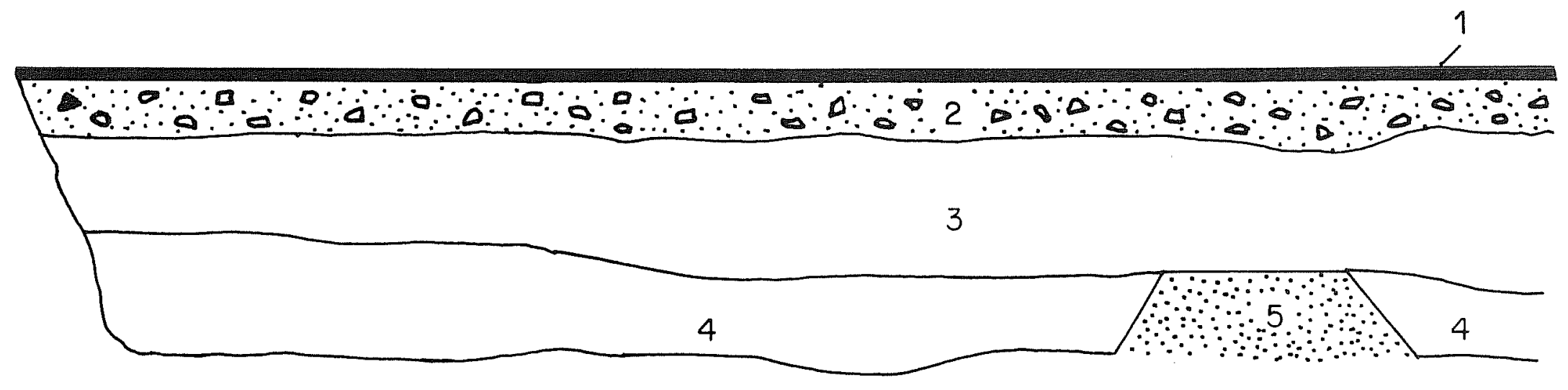

1-Asphalt

2-Limestone base material

3-Dark gray clay

4-Sterile caliche

5 -Concrete footing

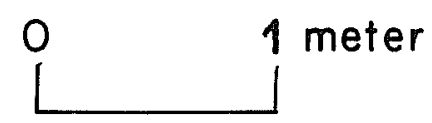

$41 \mathrm{~B} \times 677$

TRENCH 7

PROFILE-NORTH WALL

Figure 10. Test Trench 7, North Wall Profile. 


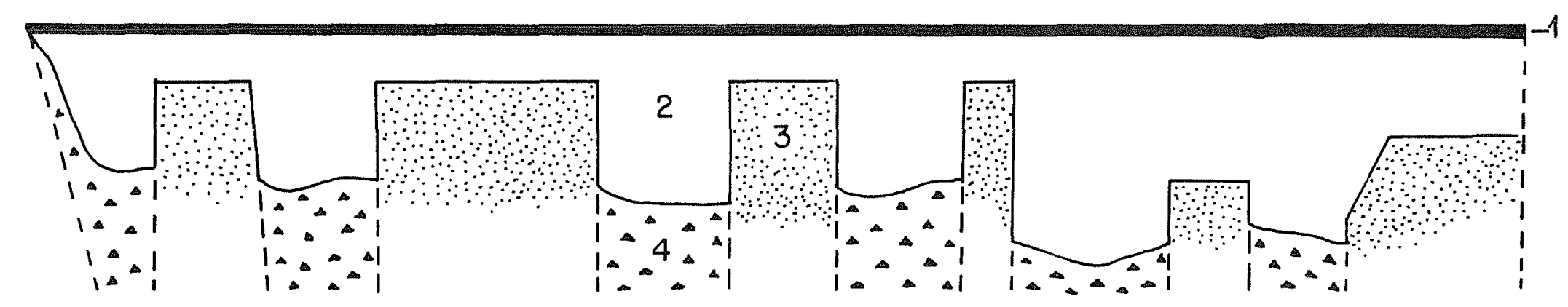

1 - Asphalt

2-Construction debris

3-Concrete footings

4- Building rubble

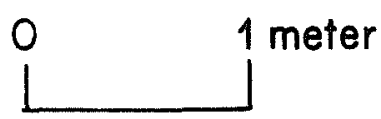

\author{
$41 \mathrm{~B} \times 677$ \\ TRENCH 8 \\ PROFILE-NORTH WALL
}

Figure 11. Test Trench 8, North Wall Profile. 
particular type or model of machinery has already been pinpointed (usually to within a decade) through historical research. A no-earlier-than date can then be ascribed for a particular process, meaning that the artifact could not have been made before a certain date. For example, cut wire nails, machine cut from long rolls of wire, replaced the square nail as the standard, and were loca 11 y available by about 1880 (Anne A. Fox, persona 1 communication). The "crown cork," today most commonly used on the returnable carbonated soda bottles, was first patented by William Painter in 1891 (Munsey 1970:105). Technological analysis though, does not work well for al1 material classes of historical artifacts, and is only one of the many analytical tools available by which to ascribe a temporal placement for a particular artifact.

Descriptive analysis works well when technological analysis is not feasible. This type of analysis works particularly well on 1ate 19th- and early 20thcentury glass containers. The shape alone for a particular vessel may indicate the bottle's original contents (perfume, beverage, snuff, ink, medicine). Late 19th-century (post-Civil War) glass containers frequentiy have embossed lettering molded into the glass during the manufacturing process, which state the contents, manufacturer, distributor, or p 1 ace of origin for the product. In such cases, historical research can more precisely date the bottle than can an analysis of the technology used to make the bottle.

Ceramics are perhaps the most temporally sensitive class of historic artifacts found at most sites. Ceramic chronologies for San Antonio span over 900 years, beginning with the aboriginally produced Leon P1ain ceramics (ca. A.D. 1000). Excavations on the northern half of Lot 6 (Fairmount I Project) produced over 10,000 sherds which date from 1830 to 1850. Many are transfer-printed pearlwares produced in England. This ceramic assemblage contains nearly complete examples of pearlware bow 15 , p 1 ates, teacups, saucers, a chamber pot, and part of a serving platter. The different vessel shapes, particularly the teacups, saucers, and plates, often have the same floral or scenic transfer pattern. A single motif may be represented in brown, black, green, blue, red, or purple monochrome transfers. Many of the vessels also have potters or makers' marks which indicate the manufacturer or country of origin (e.g., Davenport, London). Some also have importers' stamps (e.g., Henderson and Gains, Hill and Henderson, New Orleans) indicating the port of entry into the United States from abroad. The continuing research with La Villita Earthworks site (4I BX 677) ceramic assemb 1 age wil1 undoubted 1 y 1 ead to a refinement in the present ceramic seriations for the 18th- and 19th-century chronologies for San Antonio (Labadie 1986).

The artifact sample recovered by the Fairmount II Project (Tab1e 2) has no direct connection to the Mexican siege works (La Vili ita Earthworks site, $41 \mathrm{BX} 677$ ) found on the northern part of Lot 6. A few ceramic sherds (Fig. 6,a-n) of comparable age were found during the Fairmount II Project testing, but, in a 11 cases, were recovered from disturbed contexts (e.g., Trench 7, Fig. 10). Only Feature 1, in Trench 6, had cultural materials (Fig. 9,a-e) that were sti11 in a primary context; al1 of which date after 1880. 


\section{SUMMARY AND CONCLUSIONS}

The archaeological testing of the southern portion of New City Block (NCB) 155 failed to identify any significant cultural features or deposits similar to those identified by the Fairmount I Project on the northern portion of the same lot. The crew, however, was not able to perform a $100 \%$ areal coverage on the southern portion of Lot 6 .

Historical research indicated that the highest probability for 1 locating buried cultural deposits existed along the southern and western lot perimeters; these two areas were not adequately tested by this survey due to the presence of construction debris, a Saltillo tile sidewalk, and asphalt paving (see Fig. 4). Testing of these areas is recommended before any construction.

A single intact archaeological feature was isolated near the western property 1 ine which consisted of a fire brick-l ined incinerator (or former privy) filled with ashen deposits and a variety of residential trash. The feature was completely excavated and recorded. The exact construction date for this feature is not known, but it appears to have been in use by about 1880 and continued to be used intermittently for rubbish disposal through the early 20 th century (ca. 1930).

It is felt by this author that Feature 1 should not be designated by a separate trinominal site number. It is common to find multiple historic features, from several historic periods, within a single designated site (or city 1ot). We consider site 41 BX 677 to include the entirety of Lot 6 which has been tested under two different Texas Antiquities Committee (TAC) permits (480 and 505). Artifacts from site 41 BX 677 were recovered from either the "A" phase of testing (480) or the "B" phase of testing (505).

Subsurface soil, to an average depth of $\mathrm{ca} .50 \mathrm{~cm}$ from the present-day street 1 evel on South $A 1$ amo and East Nueva Streets, has been totally disturbed by 20th-century construction and/or demolition activities. Intrusive disturbances were found to a depth of ca. $1.9 \mathrm{~m}$. This zone of disturbance contained only a few randomly distributed artifacts intermixed with gravel, pieces of concrete, and rusty metal. Several sections of a concrete building foundation, attributable to the two-story brick commercial building, which once stood on this lot (built after 1927), were isolated in four of the eight test trenches.

The artifactual sample recovered consisted of 1 ate 19 th-century residential rubbish, presumably from nearby residents. Nearly all of the datable materials are attributable to the 1ate 19th or early 20 th century.

This project has determined that there are no significant cultural deposits within the area tested that would be deemed potentially eligible for nomination to the National Register of Historic Places or as a State Archeological Landmark. Therefore, we recommend that construction be allowed to proceed in areas al ready tested. We further recommend additional testing in areas inaccessible to this project on the southern portion of Lot 6 before any construction occurs. 


\section{REFERENCES CITED}

Bexar County, Texas

Bexar County Deed Records (BCDR)

Originals and microfilm in Bexar County Courthouse, San Antonio, Texas. Vols. A-2, C-1, K-2, LGS, P-2, 16, 175.

Brown, K. M.

1986 Structure and Stratigraphy of the Site. Chapter 3 in La Villita Earthworks (41 BX 677): San Antonio, Texas. A Preliminary Report of Investigations of Mexican Siege Works at the Battle of the A 1 amo, assemb 1 ed by J. H. Labadie. Center for Archaeological Research, The University of Texas at San Antonio, Archaeological Survey Report 159 (in preparation).

\section{City Directory}

1927-1928

$1933-1934$

Located in the San Antonio Main Public Library, San Antonio, Texas.

Eaton, J. D.

1980 Excavations at the Alamo Shrine (Mission San Antonio de Valero). Center for Archaeological Research. The University of Texas at San Antonio, Special Report 10.

Fox, A. A., F. Bass, Jr., and T. R. Hester

1976 The Archaeology and History of Alamo Plaza. Center for Archaeological Research. The University of Texas at San Antonio, Archaeological Survey Report 16.

Fox, D. E., F. Valdez, Jr., and L. O. Bobbitt

1978 An Archaeological Assessment of the Dolores A1drete House Property, San Antonio, Texas. Center for Archaeological Research, The University of Texas at San Antonio, Archaeological Survey Report 58.

Giraud, F.

1848 City Plat Book. Vol. 1. Contains the original maps drawn by Giraud of the New City Block numbers in San Antonio. Copy located at the San Antonio Historical Preservation Office, City Hall Annex, San Antonio. 
Habig, M. A.

1968 The Al amo Chain of Missions, A History of San Antonio's Five 01d Missions. Franciscan Herald Press, Chicago, I11 inois.

Ivey, J.E.

1978 Archaeological Investigations at the Gresser House (41 BX 369), San Antonio, Texas. Center for Archaeological Research. The University of Texas at San Antonio, ArchaeoTogical Survey Report 60.

Katz, P. R.

1978 Archaeological and Historical Investigations in the Arciniega Street Area, Downtown San Antonio, Texas. Center for Archaeological Research. The University of Texas at San Antonio, Archaeological Survey Report 61.

Koch, Augustus

1873 Bird"s Eye View of the City of San Antonio, Bexar County, Texas, 1873. Reproduced from the San Antonio Museum Association. Published by R. H. Holland.

1886 Bird's Eye View of San Antonio, Bexar County, Texas, 1886, Looking Northeast. Reproduced from the collection of the Randolph B1ueprint Company, San Antonio.

Labadie, J. H., assembler

1986 La Villita Earthworks (4l BX 677): San Antonio, Texas. A Preliminary Report of Investigations of Mexican Siege Works at the Battle of the Alamo. Center for Archaeological Research, The University of Texas at San Antonio, Archaeological Survey Report 159 (in preparation).

Maverick, M.

1939 01d La Villita. Published by the City of San Antonio, Texas. Munsey, C.

1970 The Illustrated Guide to Collecting Bottles. Hawthorn Books, New York.

Sanborn Map and Publishing Company, Ltd.

1904 Map of San Antonio, Texas. New York. 
